\title{
Adaptation and Validation of the Dispositional Hope Scale for Adolescents
}

\author{
Adaptação e Validação da Escala de Esperança Disposicional para Adolescentes \\ Juliana Cerentini Pacico*, Micheline Roat Bastianello, Cristian Zanon \& Claudio Simon Hutz \\ Universidade Federal do Rio Grande do Sul, Porto Alegre, Rio Grande do Sul, Brasil
}

\begin{abstract}
This paper describes the psychometric features and the validation process of the Adult Dispositional Hope Scale (ADHS) for adolescents in the south of Brazil. This scale measures the Hope construct in terms of pathways and agency. The ADHS was translated to Portuguese and underwent a reverse translation. A sample of 450 students, from 14 to 18 years old ( $M=16.8$ years, $S D=3.4$, $56 \%$ female), answered the ADHS, the Hope Index, the LOT-R and the Rosenberg's Self-Esteem Scale. A factorial analysis with varimax rotation showed that the scale is unidimensional and that its internal consistency was adequate (Cronbach's alpha $=.80$ ). No significant gender differences were found. Correlations of ADHS with the other constructs presented evidence of convergent validity in the present study.

Keywords: Dispositional Hope Scale, hope, positive psychology.

Resumo

Este trabalho descreve o processo de validação e características psicométricas da Adult Dispositional Hope Scale (ADHS) para adolescentes do sul do Brasil. Esta escala avalia o construto Esperança em termos de rotas e agenciamento. A ADHS foi traduzida para o português e submetida a uma tradução reversa. Uma amostra de 450 estudantes entre 14 e 18 anos de idade $(M=16,8, D P=3,4$, $56 \%$ do sexo feminino) responderam a ADHS, a Hope Index, o LOT-R e a Escala de Autoestima de Rosenberg. A analise fatorial com rotação varimax mostrou que o instrumento é unidimensional e que sua consistência interna é adequada (Alfa de Cronbach= 0,80 . Não foram encontradas diferenças entre os gêneros. As correlações da ADHS com outros construtos conferem evidências de validade convergente ao estudo.

Palavras-chave: Dispositional Hope Scale (ADHS), esperança, psicologia positiva.
\end{abstract}

Hope has been described, measured and studied in different ways and by different areas of human knowledge, as Philosophy, Theology, Education and Psychology (Edwards, 2009). In the last 20 years, from the development of Snyder's theory (1995, 2000a, 2000b) onwards, studies about Hope have received greater attention within the field of Positive Psychology (Snyder \& Lopez, 2009). In Brazil there are not valid instruments to measure hope in adolescents. Then, the present study aims to adapt and validate the Dispositional Adult Hope Scale (Snyder et al., 2001) for use in Brazil with adolescents. The specific objective was to investigate the

\footnotetext{
* Mailing address: Federal University of Rio Grande do Sul, 2600 Ramiro Barcelos St, Porto Alegre, Rs, Brazil 900035-003. E-mail: jucerentini@hotmail.com, mbastianello@hotmail.com, crstn.zan@gmail.com e claudio. hutz@terra.com.br

This paper is part of the thesis of the first author, entitled "Adaptação e Validação de Instrumentos para Avaliação de Esperança". This work was registered by the Ethics Comitee at the Federal University of Rio Grande do Sul under the code 2009058 and was supported by $\mathrm{CNPq}$ and CAPES.
}

relationship among hope (dispositional and cognitive), optimism and self- esteem.

Snyder (1995) states that Hope is a construct based upon realistic evaluations about desires and the means to achieve them. Researchers agree with the premise that Hope is related to positive expectations about obtaining an objective (Creamer et al., 2009). In the same respect, Snyder and Lopes (2005) proposed that Hope is the thinking directed to objectives and composed of pathways and agency.

The pathways refer to the capacity to generating suitable paths for obtaining the objective desired. They can also be understood to be the paths perceived so that the objective can be attained (Creamer et al., 2009; Roesch \& Vaughn, 2006; Snyder \& Lopez, 2007). Producing several pathways is particularly important when barriers arise between the subject and the objective. By having various pathways, the individual can easily find an alternate path upon coming up against obstacles.

The agency is the motivating component which drives the search for the objective, using the pathways (Snyder \& Lopez, 2009). It is described as the belief in one's own 
skill in using the pathways and achieving the objectives proposed. People high in agency are characterized by determination, motivation and energy directed towards obtaining results (Creamer et al., 2009). This component is essential in seeking any goal, but is more strongly emphasized when obstacles occur (Snyder \& Lopez, 2005). Only objectives of considerable value to the individual have agency, i.e., motivation to be achieved (Snyder \& Lopez, 2007). Although it is composed of two factors, hope is "a positive motivational state that is based on an interactively derived sense of successful (a) agency (goal directed energy) and (b) pathways (planning to meet goals)" (Snyder et al., 1991, p. 287).

Several authors have constructed instruments in order to evaluate Hope and better understand its influence on the lives of adolescents and adults (Edwards, Ong, \& Lopez, 2007). However, few have appropriate psychometric features. Snyder developed two scales: the State Hope Scale (Snyder et al., 1996) and the Adult Dispositional Hope Scale (Snyder et al., 1991). The first scale evaluates Hope being sensitive to the variances which occur in short periods of time. It is rather useful when the objective is to evaluate the effects of a treatment or intervention concerning Hope. Whereas the second one measures Hope as having a more permanent nature, stable in time, and so dispositional, which indicates temperament, trait. Thus, the age range for which it is intended is that of adolescents who are at least 15 years old.

According to Snyder (2000a), Hope starts to develop in childhood, being reinforced throughout development. The pathways begin to develop when children learn the temporal relations between their actions and the results thereof. The agency, in turn, emerges when the child becomes aware that (s)he is the subject of his/her actions (Creamer et al., 2009).

The evaluation of Hope, through instruments such as this one proposed by Snyder and colleagues (2001), contributes to clarifying the relations of Hope with other constructs, which allows greater understanding about human development. Biswas-Diener and Patterson (2011) said that it positive process emotions, prospective emotions (e.g., hope), and retrospective emotions are positively related to motivation to study, effective study strategy. Students high in Hope have high scores in positive social interactions and school grades, as well as possessing high self-esteem and being very optimistic (Snyder, Cheavens, \& Sympson, 1997; Snyder, Hoza et al., 1997; Valle, Huebner, \& Suldo, 2006). To evaluate the convergent validity, the present study examined the correlations among hope, self-esteem and optimism in Brazilian adolescents.

Other results indicate that Hope is positively related to overall life satisfaction (Roesch \& Vaughn, 2006; Valle, Huebner, \& Suldo, 2004), being associated with efficient strategies of coping with and resolving problems (Bellizzi \& Blank, 2006; Chang, 2003). A good academic and physical performance (Ciarrochi, Heaven, \& Davies, 2007) are associated with high scores in Hope. This relation is repeated regarding work (Peterson \& Byron, 2008).

\section{Method}

\section{Participants}

Participants were 450 students of the first, second and third years of elementary school, aged between 14 and 18 years old, the average age being 16.8 years $(S D=3.4)$. Of this total, 383 came from schools of public education, and 87 attended private schools. About $56 \%$ of the students were female and $44 \%$ male.

The sample was chosen for reasons of convenience and the students took part on a voluntary basis. The signing of an informed consent by the parents was also a requirement for taking part in the survey.

\section{Instruments}

The participants answered the Dispositional Hope Scale for Adults (Snyder et al., 1991). This instrument contains 12 items. Four of them refer to the agency dimension, four refer to the pathways dimension, and the remaining four items are distractors. The items are answered on a five- point Likert type scale where 1 means totally false and 5 , totally true. The internal consistency of the original instrument (Cronbach's alpha) was .71 thru .84. The following instruments were also applied, in order to check the convergent validity: The Hope Index (Pacico, Bastianello, Zanon, \& Hutz, 2011; Staats, 1989), Life Orientation Test Revised-LOT-R, (Bastianello, Pacico, Zanon, \& Hutz, manuscript submitted; Scheier, Carver, \& Bridges, 1994) and Rosenberg's Self-Esteem Scale (Hutz \& Zanon, 2011; Rosenberg, 1989).

The Hope Index has 21 items. For each item the subject marks on the left how much (s)he desires the item on the right, and how much (s)he believes that the item will occur, using a scale of 0 thru 5 points. According to Staats (1989), this instrument would have four subscales: Hope-self, Hope-other, Desire and Expectation. The adapted instrument had appropriate internal consistency (hope-self .83 and hope-other .81), being similar to the values obtained in the original study (Pacico, Bastianello, Zanon, \& Hutz, 2013).

The Life Orientation Test Reviewed (LOT-R) is a selfreport test to measure the dispositional optimism described by Scheier et al. (1994) and adapted and validated for Brazilian adolescents by Bastianello et al. (2013). The instrument consists of 10 items, four of them being distractors. The subjects answer the statements indicating their degree of agreement on a Likert scale of 5 points, varying from complete disagreement to full agreement. The adapted LOT-R has good internal consistency, similar to the original study (Cronbach's alpha .80).

Rosenberg's Self-Esteem Scale (Hutz \& Zanon, 2011) is a one dimensional self-report measure of self-esteem. A four-point likert scale is used to answer each item. 
It is composed of closed 10 questions related to satisfaction with oneself, with one's qualities and capacities, with the very value, pride and respect for oneself, a positive attitude related to oneself, a feeling of uselessness and a sensation of failure. The instrument has displayed good psychometric features (Cronbach's alpha .90).

\section{Procedures}

Initially the Hope test was translated into Portuguese, and then translated back into English. Judges fluent in English analyzed the original instrument and the ensuing back translation version to check if they were semantically equivalent.

Then, the version in Portuguese was applied to a pilot sample to check the understanding of the items and application instructions. It was not identified the necessity of any change in the items. Data started to be collected when it had been established that the items of the instrument were intelligible and understandable to groups of high school and university student and that the instructions given were adequate.

The instruments were applied collectively in the classroom. The participants were informed about the objective of the survey, ensured of the nondisclosure of the data and that participation was voluntary. Then, they were given instructions about how to fill in the questionnaires.

\section{Results}

\section{Factorial Structure of the Hope Scale}

The set of eight items of the Hope Scale was submitted to a factorial analysis (varimax rotation). As can be seen in the scree plot (Figure 1), the results indicated the presence of a single factor, with an eigenvalue of 3.35 , which explained approximately $41.8 \%$ of the total variance. The Kaiser-Meyer-Olkin index was .87 and Bartlett's test of sphericity was significant $(p<.001)$. The communalities of the items ranged from .32 to .52 . All the items had componential loads exceeding .58. The internal consistency of the scale was good (Cronbach's alpha $=.80$ ). There were no significant differences between the Hope means for men $(M=32.1 ; S D=5.0)$ and for women $(M$ $=32.4 ; S D=4.6)[t(424)=.6 ; p>.05]$. The mean for the entire sample was $32.2(S D=4.8)$. A confirmatory factor analysis (CFA) was conducted to evaluate model fit using EQS 6.1 (maximum likelihood estimation). Unidimensionality was supported: $\chi^{2}(20)=45.62, p<.001$, RMSEA $=.45, \mathrm{CFI}=.97$.

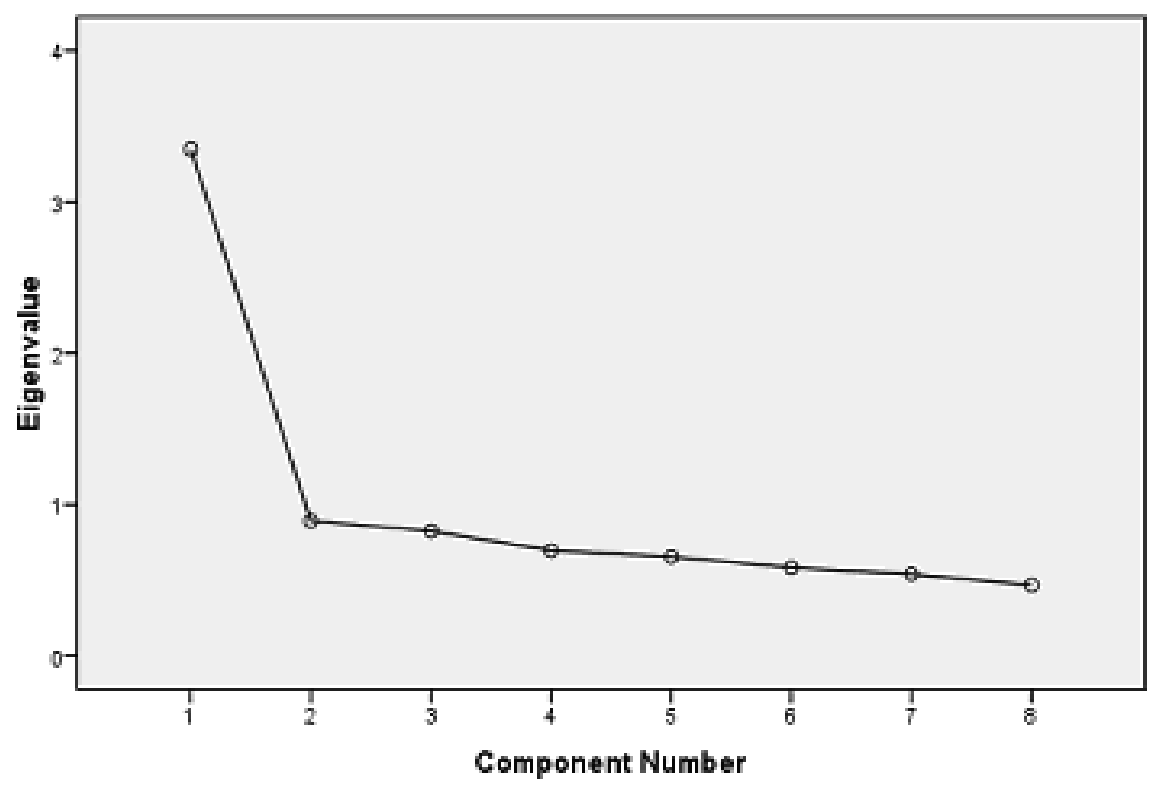

Figure 1. Scree plot of the Dispositional Hope Scale items.

Evidence of Convergent Validity of the Hope Scale

To evaluate the relationship between dispositional Hope and the other variables, Pearson correlation analyses were executed. Table 1 shows the results of the analysis. In general, positive and moderate correlations were found between dispositional Hope and the other variables. As these correlations are similar to the ones reported in most studies, these results sugest convergent validity between the Hope Scale with The Hope Index, Life Orientation Test Revised-LOT-R, and Rosenberg's Self-Esteem Scale. 
Pacico, J. C., Bastianello, M. R., Zanon, C. \& Hutz, C. S. (2013). Adaptation and Validation of the Dispositional Hope Scale for Adolescents.

Table 1

Correlations between Dispositional Hope and Cognitive Hope, Optimims, and Self-Esteem

Variables

(1)

(2)

\begin{tabular}{llll}
\hline (1) Dispositional Hope & - & & \\
(2) Cognitve Hope & .43 & - & \\
(3) Self-esteem & .55 & .43 & - \\
(4) Optimism & .49 & .42 & .60 \\
\hline
\end{tabular}

Note. All correlations were significant $(p<.01)$.

\section{Discussion}

The main objective of this study was to adapt and validate the Adult Dispositional Hope Scale (Snyder et al., 2001). There is some disagreement in the literature about the factorial structure of the Hope scale. Some researchers have found two factors and others just one factor. Babyak, Snyder and Yoshinobu (1993) conducted a confirmatory factorial analysis and concluded that the two-factor model was significantly better than the model of one factor representing general Hope. Other authors as Roesch and Vaughn (2006) support this interpretation. However, the two factors seem to be highly correlated $(r>.80)$ in several studies. Such high correlations produce doubts about the existence of two factors. Arnau, Rosen, Finch, Rhudy and Fortunato (2007) suggest that when scale components that share much of common variance are treated as separate dimensions, the results from validity studies are not reliable.

Brouwer, Meijer, Weekers and Baneke (2008) found that the best solution for the structure of this scale was unidimensional, namely Dispositional Hope. They stated that when they used a bifactorial model, there was no general factor which explained the intercorrelation of the items.

The results found in the presente study corroborate the findings of Brouwer, Meijer, Weekers and Baneke (2008). The factorial analysis in our study extracted only one factor with an eingevalue greater than one. Thus, for our sample, the best solution for the componential structure of the instrument is the unidimensional model. Agency and pathways both contribute to the variability of a single larger dimension, Dispositional Hope.

A possible explanation for the unidimensional structure was given by Roesch and Vaughn (2006). They stated that during the testing it is not clear if the participants perceive pathways and agency as separate constructs. Thus, they could perceive them as being equal generating a single factor, Dispositional Hope. Snyder et al. (1991) state, also, that the general factor (Hope) is the best predictor of results and that it is extremely difficult to predict which of the factors - agency or pathways - are responsible for them, due to the great overlapping of variability of them both. This is why most studies about Hope are executed considering it to be the single general dimension (Roesch \& Vaughn, 2006). Arnau et al. (2007) also suggest that agency and pathways do not necessarily make single and independent contributions to the construct of Hope, even because, as stated by Snyder et al. (1991), agency and pathways are independent but highly related constructs. This may be the factor generating divergence concerning the factorial structure of the scale; this correlation can be so large that it indicates the presence of a single factor.

Thus, we can conclude that, for the sample selected, the unidimensional solution is the most satisfactory one, considering that the factorial analysis showed the presence of only one component more relevant with an eigenvalue of 3.35 , explaining $41.8 \%$ of the total variance. All the items had a componential load exceeding .56 and the internal consistency of the scale was quite adequate (Cronbach's alpha $=.80)$ and within the parameters already found in the relevant literature (Snyder et al., 1991).

No sex-related differences were observed in the scores of the hope scale. Men and women do not differ regarding hope. This had already been observed by Creamer et al. (2009), Roesch and Vaughn (2006) and Snyder (1995) who also did not find any sex-related differences in their studies.

Evidence of convergent validity of the scale was found through the relation of the instrument with optimism, self-esteem and Cognitive Hope. Moreover, similar surveys confirm the results obtained: Roesch and Vaughn (2006) reported the positive correlation of Dispositional Hope with self-esteem and optimism (Snyder et al., 1991), at the same time as being different constructs (Bandura, 1982; Scheier \& Carver, 1985; Valle et al., 2004). The relation with other adaptive behavior has been widely reported in the relevant literature (Magaletta \& Oliver, 1999; Snyder, Cheavens et al., 1997; Snyder et al., 1991).

In conclusion, the results of the present study indicate that the scale is valid to measure hope in Brazilian adolescents. Further studies will be needed to generalize the results to other regions of Brazil.

\section{References}

Arnau, R. C., Rosen, D. H., Finch, J. F., Rhudy, J. L., \& Fortunato, V. J. (2007). Longitudinal effects of hope on depression and anxiety: A latent variable analysis. Journal of Personality, 75, 43-64.

Babyak, M. A., Snyder, C. F., \& Yoshinobu, L. (1993). Psychometric properties of the Hope Scale: A confirmatory factor analysis. Journal of Research in Personality, 27, 154-169.

Bandura, A. (1982). Self-efficacy mechanism in human agency. American Psychologist, 37, 122-147.

Bastianello, M. R., Pacico, J. C., Zanon, C., \& Hutz, C. S. (2013). Adaptation e validation of LOT-R. Manuscript submitted for publication.

Bellizzi, K. M., \& Blank, T. O. (2006). Predicting posttraumatic growth in breast cancer survivors. Health Psychology, 25(1), 47-56.

Biswas-Diener, R., \& Patterson, L. (2011). An experiential approach to teaching positive psychology to undergraduates. The Journal of Positive Psychology: Dedicated to Furthering Research and Promoting Good Practice, 6(6), 477-481. 
Brouwer, D., Meijer, R. R., Weekers, A. M., \& Baneke, J. J. (2008). On the dimensionality of the Dispositional Hope Scale. Psychological Assessment, 20(3), 310-315.

Chang, E. C. (2003). A critical appraisal and extension of hope theory in middle-aged men and women: Is it important to distinguish agency and pathways components? Journal of Social \& Clinical Psychology, 22, 121-143.

Ciarrochi, J., Heaven, P. C. L., \& Davies, F. (2007). The impact of hope, self-esteem, and attributional style on adolescents' school grades and emotional well-being: A longitudinal study. Journal of Research in Personality, 41(6), 1161-1178.

Creamer, M., O’Donnell, M. L., Carboon, I., Lewis, V., Densley, K., McFarlane, A., ...Bryant, R. A. (2009). Evaluation of the Dispositional Hope Scale in injury survivors. Journal of Research in Personality, 43(4), 613-617.

Edwards, L. M. (2009). Hope. In S. J. Lopez (Ed.), Encyclopedia of Positive Psychology (Vol. 1, pp. 487-491). Hoboken, NJ: Wiley.

Edwards, L. M., Ong, A. D., \& Lopez, S. J. (2007). Hope measurement in Mexican youth. Hispanic Journal of Behavioral Sciences, 29(2), 225-241.

Hutz, S. C., \& Zanon, C. (2011). Revision of the adaptation and validation of the Rosenberg's Self-esteem Scale. Avaliação Psicológica, 11, 41-49.

Magaletta, P. R., \& Oliver, J. M. (1999). The hope construct, will, and ways: Their relations with self-efficacy, optimism, and general well-being. Journal of Clinical Psychology, 55(5), 539-551.

Pacico, J. C., Bastianello, M. R., Zanon, C., \& Hutz, C. S. (2011). Adaptation and validation of the Hope Index for Brazilian adolescents. Psicologia: Reflexão e Crítica, 24, 666-670.

Pacico, J. C., Bastianello, M. R., Zanon, C., \& Hutz, C. S. (2013). Adaptation and Validation of the Brazilian version of the Hope Index. International Journal of Testing, 13, 193-200.

Peterson, S. J., \& Byron, K. (2008). Exploring the role of hope in job performance: Results from four studies. Journal of Organizational Behaviour, 29, 785-803.

Roesch, S. C., \& Vaughn, A. A. (2006). Evidence for the factorial validity of the Dispositional Hope Scale, cross-ethnic and cross-gender measurement equivalence. European Journal of Psychological Assessment, 22, 78-84.

Rosenberg, M. (1989). Society and the adolescent self-image (Rev. ed.). Middletown, CT: Wesleyan University Press.

Scheier, M. F., \& Carver, C. S. (1985). Optimism, coping, and health: Assessment and implications of generalized outcome expectancies. Health Psychology, 4, 219-247.

Scheier, M. F., Carver, C. S., \& Bridges, M. W. (1994). Distinguishing optimism from neuroticism (and trait anxiety, self-mastery, and self-esteem): A reevaluation of the Life Orientation Test. Journal of Personality and Social Psychology, 67, 1063-1078.

Snyder, C. R. (1995). Conceptualizing, measuring, and nurturing hope. Journal of Counseling and Development, 73, 355-360.

Snyder, C. R. (2000a). The past and future of hope. Journal of Social and Clinical Psychology, 19, 11-28.

Snyder, C. R. (2000b). Handbook of hope: Theory, measures, and applications. San Diego, CA: Academic Press.

Snyder, C. R., Cheavens, J., \& Sympson, S. C. (1997). Hope: An individual motive for social commerce. Group Dynamics: Theory, Research, and Practice, 1, 107-118.

Snyder, C. R., \& Lopez, S. J. (2005). Handbook of positive psychology. New York: Oxford University Press.
Snyder, C. R., \& Lopez, S. J. (2007). Positive psychology: The scientific and pratical explorations of human strengths. Thousand Oaks, CA: Sage.

Snyder, C. R., \& Lopez, S. J. (2009). Psicologia positiva: Uma abordagem científica e prática das qualidades humanas. Porto Alegre, RS: Artmed.

Snyder, C. R., Harris, C., Anderson, J. R., Holleran, S. A., Irving, L. M., Sigmon, S. T., ... Harney, P. (1991). The will and the ways: Development and validation of an individual-differences measure of hope. Journal of Personality and Social Psychology, 6, 570-585.

Snyder, C. R., Hoza, B., Pelham, W. E., Rapoff, M., Ware, L., Danovsky, M., ...Stahl, K. (1997). The development and validation of the Children's Hope Scale. Journal of Pediatric Psychology, 22(3), 399-421.

Snyder, C. R., Sympson, S. C., Ybasco, F. C., Borders, T. F., Babyak, M. A., \& Higgins, R. L. (1996). Developmento and validation of the State Hope Scale. Journal of Personality and Social Psychology, 70, 321-335.

Staats, S. (1989). Hope - A comparison of two self-report measures for adults. Journal of Personality Assessment, 53(2), 366-375.

Valle, M. F., Huebner, E. S., \& Suldo, S. M. (2004). Further evaluation of the Children's Hope Scale. Journal of Psychoeducational Assessment, 22(4), 320-337.

Valle, M. F., Huebner, E. S., \& Suldo, S. M. (2006). An analysis of hope as a psychological strength. Journal of School Psychology, 44(5), 393-406.
Recebido: 30/05/2012 $1^{a}$ revisão: $13 / 09 / 2012$ Aceite final: 14/09/2012 